\title{
THIN LAYER DRYING KINETICS OF MANGO PUREE IN REFRACTANCE WINDOW DRYING SYSTEM
}

\author{
B. M. A. Amer*
}

\section{ABSTRACT}

Drying of mango puree in a pilot Refractance Window system was investigated to determine mass transfer (moisture diffusivity) characteristics at two conveyor speeds. A theoretical approach based on mass transfer kinetics is used to model the change in moisture content of the food product. Moisture content of mango puree collected at different locations on the belt during drying was fitted to various thin-layer models. The models were compared using five statistical parameters, i.e. coefficient of determination $\left(R^{2}\right)$, reduced mean square of the deviation $\left(\chi^{2}\right)$, root mean square error (RMSE), and modeling efficiency $(E F)$. Based on the values of these statistical parameters obtained, the two term model represented drying characteristics better than other models. The moisture diffusivity during $R W$ drying process at conveyor speeds of $0.0065 \mathrm{~m} \mathrm{~s}^{-1}$ and $0.0078 \mathrm{~m} \mathrm{~s}^{-1}$ was $6.07 \times 10^{-10}$ and $8.74 \times 10^{-10} \mathrm{~m}^{2} / \mathrm{s}$, respectively. This paper presents an analytical approach for the Refractance Window drying of mango puree and the results are important for future validation studies using other products.

\section{INTRODUCTION}

7 he Refractance Window drying (RW) system illustrated in Fig. 1 utilizes circulating hot water, usually close to but below boiling

point $\left(\sim 95\right.$ to $\left.97^{\circ} \mathrm{C}\right)$ and at atmospheric pressure, to carry thermal energy for drying of materials within a very short time (around 5 minutes). Thermal energy from the circulating hot water is transferred to the wet product via a plastic interface that is relatively transparent to thermal radiation.

*Lec., Agric. Eng.; Fac. of Agric.; Cairo University-Egypt 


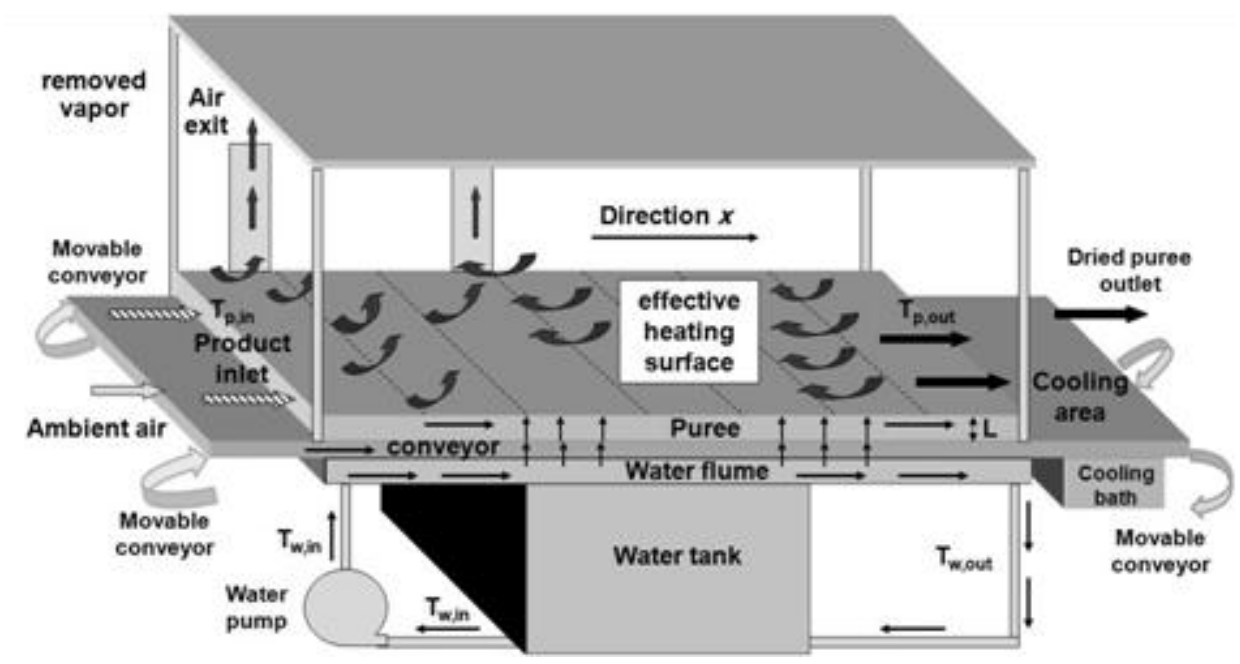

Fig.(1): Schematic diagram of Refractance Window drying system showing temperatures from the circulating hot water to the product.

Juice, purees, suspensions and similar products are spread on a transparent plastic conveyor belt that moves while its bottom surface is in contact with hot water circulating on shallow troughs (Nindo and Tang, 2007). Nindo et al., (2007), reported that proper control of temperature of circulating water is crucial for smooth operation and for improvement of system throughput and for retention of heat-sensitive compounds in juice. If the process water temperature comes close to boiling point, vapor will fill the water-plastic side of the evaporator's heat exchange area and distort the flexible evaporation surface causing a reduction in the transfer of thermal energy to the liquid product.

The hot water is recycled and reused thereby improving the thermal efficiency of the system. The use of hot water as the heat transfer medium and at temperatures just below boiling is a design feature that is unique to this drying method. After passing the heating zone, the plastic conveyor carrying the dried products then moves over a cold water trough before the products are scrapped off the belt. The product is tempered as cold water circulates under the belt, which enables easy separation of the product from the belt by a scraper device. This system is designed for drying of materials as thin-layers or films. Thus, thin-layer drying model 
may be suited to describe the drying process (Chakraverty and Singh, 1988).

Several researchers have investigated the drying kinetics of various agricultural products in order to determine the best mathematical models for describing thin-layer drying foods, such as potato slices (Akpinar $\boldsymbol{e t}$ al., 2003), and raw mango slices (Goyal et al. 2006). Although a considerable amount of data has been reported in the literature regarding the thin-layer drying modeling of various agricultural products including fruits, crops and vegetables (Maskan et al., 2002; Ratti and Kudra, 2006; Lee and Hsieh, 2008), little information is available on modeling of drying purees using the Refractance Window system.

Several successful studies have reported on drying of vegetables and fruits using Refractance Window method have been done (Nindo, at al., 2003; Nindo, et al., 2004). However, detailed modeling work on mass transfer and moisture diffusivity during RW drying of purees or juice has not been reported. Therefore the objective of present study is to develop moisture transfer models for thin-layer drying of purees on scale Refractance Window drying system. In this work, we selected mango puree as a model product because of its good consistency that facilitates easy application on the belt and investigation of drying characteristics in single layer to evaluate the suitability of some thin layer drying models.

\section{MATERIALS AND METHODS}

\section{A. Preparation of mango purees}

Frozen mango purees were imported from The Philippines and transported in the same state to American company called MCD Technologies, Inc., (Tacoma, Washington State) for drying studies. This was done to reduce possible quality degradation of the mango puree before the start of experiments. Mango puree was used as a model food in these studies because of its good film-forming ability. For the energy studies, the frozen purees were thawed in cold storage at $4^{\circ} \mathrm{C}$ for about 24 $\mathrm{h}$. The purees were then well mixed and allowed to condition at room temperature for 6 to $8 \mathrm{~h}$ before using in the experiments. 


\section{B. Heat and mass balance for Refractance Window drying system}

The exchange of moisture between the product and the air inside the dryer satisfies a mass balance relationship where moisture lost by the product is picked up by air.

The rate of convective heat transfer from the surface of product to the air, $Q$ is given as: $\quad Q=U A(\Delta T)$ where

$U$ heat transfer coefficient from air to the surface of wet material, $\left(\mathrm{kW} \cdot \mathrm{m}^{-2} \cdot{ }^{\circ} \mathrm{C}^{-1}\right)$

$\Delta \mathrm{T}$ temperature difference between air and the product surface, $\left({ }^{\circ} \mathrm{C}\right)$;

A area through which the transfer is taking place, $\left(\mathrm{m}^{2}\right)$.

However, the concentration of moisture at any point (on the conveyor belt) will not change with time since the measurements are taken when the system has reached steady state. The principle conservation of mass is obeyed because at any given infinitesimal section of the belt, the moisture escaping from the puree must be taken up by the air in the boundary layer (Fig.2).

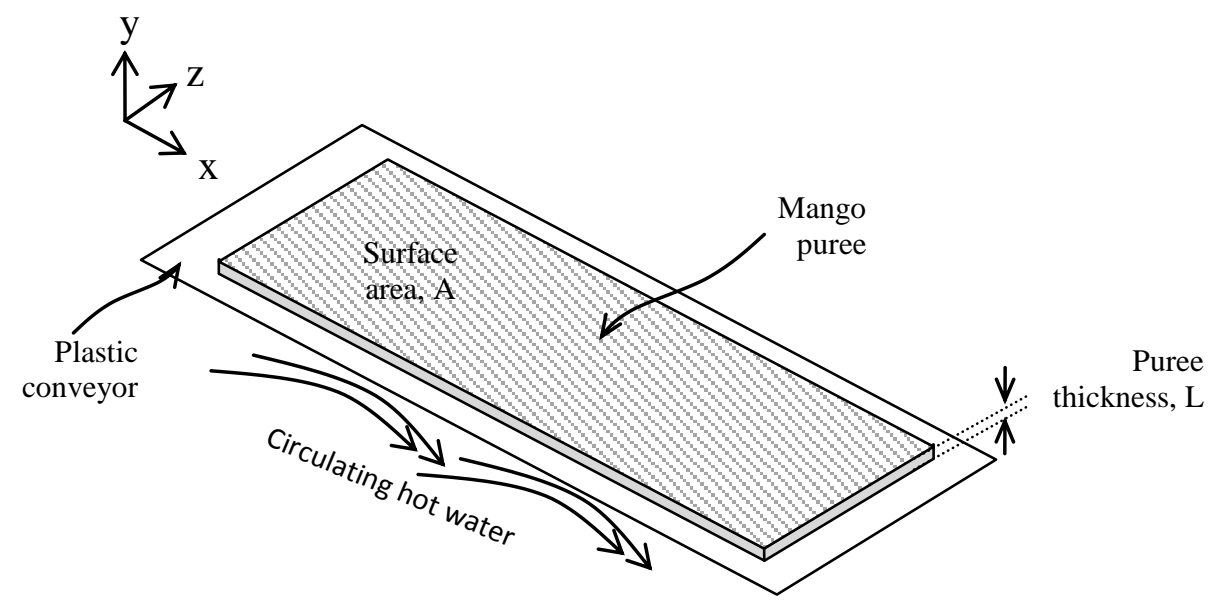

Fig.2: Illustration of mango puree on plastic surface. 


\section{Determination of the effective moisture diffusivity for puree}

From Fick's second law of diffusion (Eq.2) was used to fit the experimental data for the determination of moisture diffusivity:

$$
\frac{\partial M}{\partial t}=D_{e f f} \nabla^{2} M
$$

The solution of the previous diffusion equation for slab geometry was solved by assuming uniform initial moisture distribution, negligible external resistance, constant diffusivity, and negligible shrinkage (Crank, 1975) was used by Rajkumar et al. (2005) and (Lee and Hsieh, 2008):

$$
M R=\frac{8}{\pi^{2}} \sum_{n=0}^{\infty} \frac{1}{(2 n+1)^{2}} \exp \left(\frac{-(2 n+1)^{2} \pi^{2} D_{e f f} t}{4 L^{2}}\right)
$$

where MR is a dimensionless moisture ratio, $D_{\text {eff }}$ effective moisture diffusivity of puree $\left(\mathrm{m}^{2} \cdot \mathrm{s}^{-1}\right), t$ time (s), and $L$ half-thickness of sample $(\mathrm{m})$. This model assumes zero volume change, negligible external mass transfer resistance (infinite Biot number for mass transfer), and an isothermal process. In the heating phase of Refractance Window drying, product temperature remains fairly uniform until the cooling section is reached.

The diffusion equation developed for particles with slab geometry is applicable assuming that the diffusivity is constant and is in the form of the following equation:

$$
M R=\frac{M-M_{e}}{M_{o}-M_{e}}=\frac{8}{\pi^{2}}\left[\begin{array}{l}
\exp \left(\frac{-\pi^{2} D_{e f f} t}{4 L^{2}}\right)+\frac{1}{9} \exp \left(\frac{-9 \pi^{2} D_{e f f} t}{4 L^{2}}\right) \\
+\frac{1}{25} \exp \left(\frac{-25 \pi^{2} D_{e f f} t}{4 L^{2}}\right)+\ldots .+
\end{array}\right]
$$

For long drying times where the Fick's number is greater than 0.1 and $M \mathrm{R}<0.6$, a limiting form of equation (4), expressed in a logarithmic form, is obtained (Rahman et al., 1998; Rahman and Lamb, 1991; Madamba, 2003). After linearizing, a simplified form is obtained:

$$
\ln M R=\ln \left(\frac{8}{\pi^{2}}\right)-\left(\frac{\pi^{2} D_{e f f} t}{4 L^{2}}\right)
$$


For nonlinear experimental drying curves, the effective moisture diffusivity at various moisture ratios is determined using the ratio of slopes method. The effective diffusivities at different moisture ratios and drying time were calculated based on the ratio of the experimental drying curves to the slope of the theoretical curves at the same moisture contents.

$$
D_{\text {eff }}=\left(\frac{d M R}{d t}\right)_{\exp } /\left(\frac{d M R}{d t}\right)_{t h} \times L^{2}
$$

where $(d M R / d t)_{\exp }$ represents the slope of experimental drying curves and $(d M R / d F)_{\text {th }}$ is the slopes of theoretical curves calculated by differentiating Eq. (4) with respect to $\mathrm{F}$ (Fourier number, $F=D_{\text {eff }} t / L^{2}$ ), and taking the first term of series solution.

$$
\left(\frac{d M R}{d F}\right)_{t h}=-8 \exp \left(-\frac{\pi^{2} D_{e f f} t}{4 L^{2}}\right)
$$

The effective moisture diffusivity, $D_{\text {eff, in equations (6) and (7), was }}$ calculated simultaneously using Microsoft Excel spreadsheet program.

The average effective moisture diffusivity for each drying condition was calculated from a summation of effective diffusivity at different moisture ratio and dividing by the total number of data points (n).

$$
D_{e f f, a v e}=\frac{\sum_{1}^{n} D_{e f f}(M R)}{n}
$$

\section{Data analysis and model development}

Thin-layer models have been applied to describe drying process of various products and drying methods. Several thin layer drying models are available in the literature for explaining drying characteristics of fruits and vegetables. Among these are the ones used by Afzal and Abe (2000) for potato slices; Karathanos and Belessiotis (1999) for fig and Togrul and Pehlivan (2003) for apricot.

The drying data, reported as moisture ratio MR versus drying time, were fitted to 12 thin layer drying models. These 12 commonly used thin layer 
equations were used to fit the experimental data by the direct least square method using SPSS 16.0 software.

No relevant literature was available in which drying puree is described in a manner similar to Refractance Window process. Therefore, all the models in Table 1 were evaluated. There is, in fact, no universal model that can fit all the data. The suitability of the model is strongly dependent on the characteristics of product and drying technique.

Table 1- Mathematical models given by various authors for the drying curve

\begin{tabular}{|l|l|l|}
\hline Model Name & Model & References \\
\hline Lewis & $M R=\exp (-k t)$ & Sarsavadia et al. $(1999)$ \\
\hline Page & $M R=\exp \left(-k t^{n}\right)$ & Chhninman (1984). \\
\hline Modified Page & $M R=\exp \left(-(k t)^{n}\right)$ & White et al. (1981). \\
\hline $\begin{array}{l}\text { Henderson and } \\
\text { Pabis }\end{array}$ & $M R=a \exp (-k t)$ & $\begin{array}{l}\text { Chhninman (1984) and } \\
\text { Rahman } \text { et al. } \text { (1998). }\end{array}$ \\
\hline Logarithmic & $M R=a \exp (-k t)+c$ & Vengaiah and Pandey (2007) \\
\hline $\begin{array}{l}\text { Two-term } \\
\text { Two-term } \\
\text { exponential }\end{array}$ & $M R=a \exp \left(-k_{1} t\right)+b \exp \left(-k_{2} t\right)$ & $\begin{array}{l}\text { Henderson (1974) and } \\
\text { Rahman } \text { et al. }(1998)\end{array}$ \\
\hline Midilli et al. & $M R=a \exp (-k t)+(1-a) \exp (-k a t)$ & Sharaf-Eldeen et al. (1980) \\
\hline $\begin{array}{l}\text { Diffusion } \\
\text { approximation }\end{array}$ & $M R=a \exp (-k t)+(1-a) \exp (-k b t)$ & Kassem (1998). \\
\hline Verma et al. & $M R=a \exp (-k t)+(1-a) \exp (-g t)$ & Verma et al. (1985) \\
\hline $\begin{array}{l}\text { Simplified } \\
\text { Fick's diffusion }\end{array}$ & $M R=a \exp \left(-c\left(t / L^{2}\right)\right)$ & Diamante and Munro (1991) \\
\hline $\begin{array}{l}\text { Modified Page } \\
\text { equation-II }\end{array}$ & $M R=\exp \left(-k\left(t / L^{2}\right)^{n}\right)$ & Diamante and Munro (1991) \\
\hline
\end{tabular}

The following four statistical analysis criteria, namely, coefficient of determination $\left(\mathrm{R}^{2}\right)$, reduced chi-square or reduced mean square of the deviation $\left(\chi^{2}\right)$, root mean square error (RMSE) and modeling efficiency $(\mathrm{EF})$, have been used to evaluate the suitability of different models to fit experimental data:

$$
R^{2}=1-\frac{\sum_{1}^{N}\left(M R_{\exp i}-M R_{p r e, i}\right)^{2}}{\frac{1}{N} \sum_{1}^{N}\left(M R_{\exp \dot{\psi}}\right)^{2}}
$$




$$
\begin{aligned}
& \chi^{2}=\frac{\sum_{i=1}^{N}\left(M R_{\text {exp } \dot{t}}-M R_{p r e, i}\right)^{2}}{N-n} \\
& R M S E=\left(\frac{1}{N} \sum_{i=1}^{N}\left(M R_{p r e, i}-M R_{\exp , i}\right)^{2}\right)^{0.5} \\
& E F=\frac{\sum_{i=1}^{N}\left(M R_{\exp \dot{i}}-M R_{\exp , a v e}\right)^{2}-\sum_{i=1}^{N}\left(M R_{p r e, i}-M R_{\exp \dot{i}}\right)^{2}}{\sum_{i=1}^{N}\left(M R_{\exp \dot{\psi}}-M R_{\exp a v e}\right)^{2}}
\end{aligned}
$$

where $\mathrm{R}$;exp;i and $\mathrm{MR}$;pre; are experimental and predicted dimensionless moisture ratios, respectively; $\mathrm{N}$ is number of observations; and $\mathrm{z}$ is number of constants. The best model describing the drying characteristics of samples was chosen as the one with the highest coefficient of determination, the least reduced chi-square, root mean square error, and mean relative percentage error.

\section{RESULTS AND DISCUSSION}

\section{A. Moisture ratio and moisture diffusivity of mango puree during RW drying}

Figure 3 shows that there is a slight difference in moisture ratio (MR) of mango puree between two conveyor speeds, $0.0065 \mathrm{~m} \mathrm{~s}^{-1}$ and $0.0078 \mathrm{~m}$ $\mathrm{s}^{-1}$ at the same measured point during RW drying process. This implies that the moisture content for mango puree during RW drying for conveyor speed of $0.0078 \mathrm{~m} \mathrm{~s}^{-1}$ remained higher than moisture content at a conveyor speed of $0.0065 \mathrm{~m} \mathrm{~s}^{-1}$ most likely because of the product temperature during the process. The puree temperature increased rapidly at the beginning of drying from $20^{\circ} \mathrm{C}$ to around 70 and $65^{\circ} \mathrm{C}$ for $0.0065 \mathrm{~m}$ $\mathrm{s}^{-1}$ and $0.0078 \mathrm{~m} \mathrm{~s}^{-1}$, respectively. It then continued increasing but thereafter remained steady aroundbetween 84 and $82^{\circ} \mathrm{C}$, (Fig. 3). 


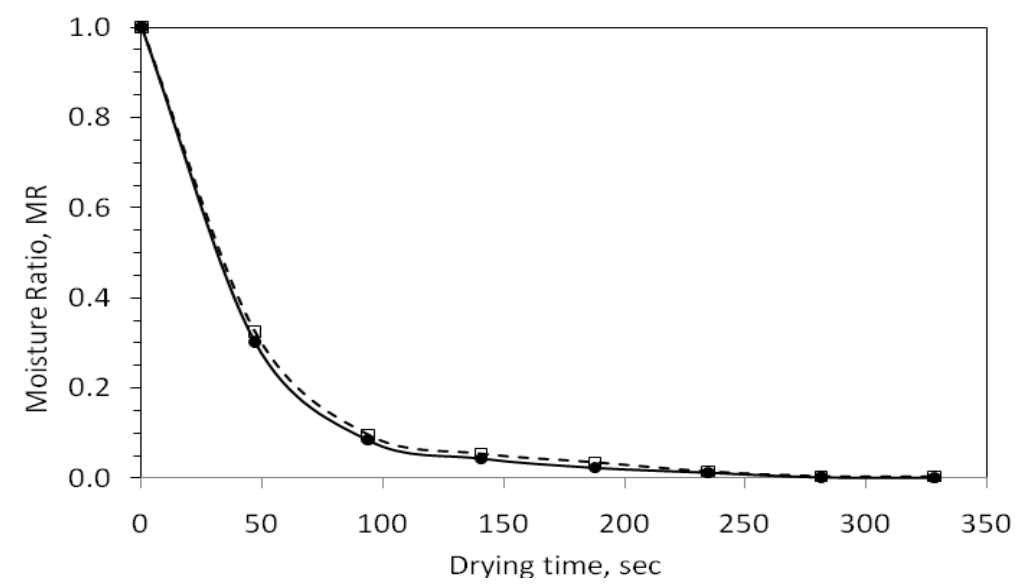

Fig. 3 - Moisture ratio versus drying time for two conveyor speeds $\left[0.0065 \mathrm{~m} \mathrm{~s}^{-1}(\bullet)\right.$ and $\left.0.0078 \mathrm{~m} \mathrm{~s}^{-1}(\square)\right]$.

A maximum diffusivity of $8.81 \times 10^{-10}$ and $8.27 \times 10^{-10} \mathrm{~m}^{2} \mathrm{~s}^{-1}$ was recorded for $0.0065 \mathrm{~m} \mathrm{~s}^{-1}$ and $0.0078 \mathrm{~m} \mathrm{~s}^{-1}$, respectively (Fig. 4). The higher value of $D_{\text {eff }}$ corresponded to a higher temperature $\left(79.8^{\circ} \mathrm{C}\right)$ while the higher speed resulted in a maximum diffusity occuring at lower temperature $\left(75.6^{\circ} \mathrm{C}\right)$. The higher value of $D_{\text {eff }}$ was obtained at the highest drying air temperatures with the thickest samples.

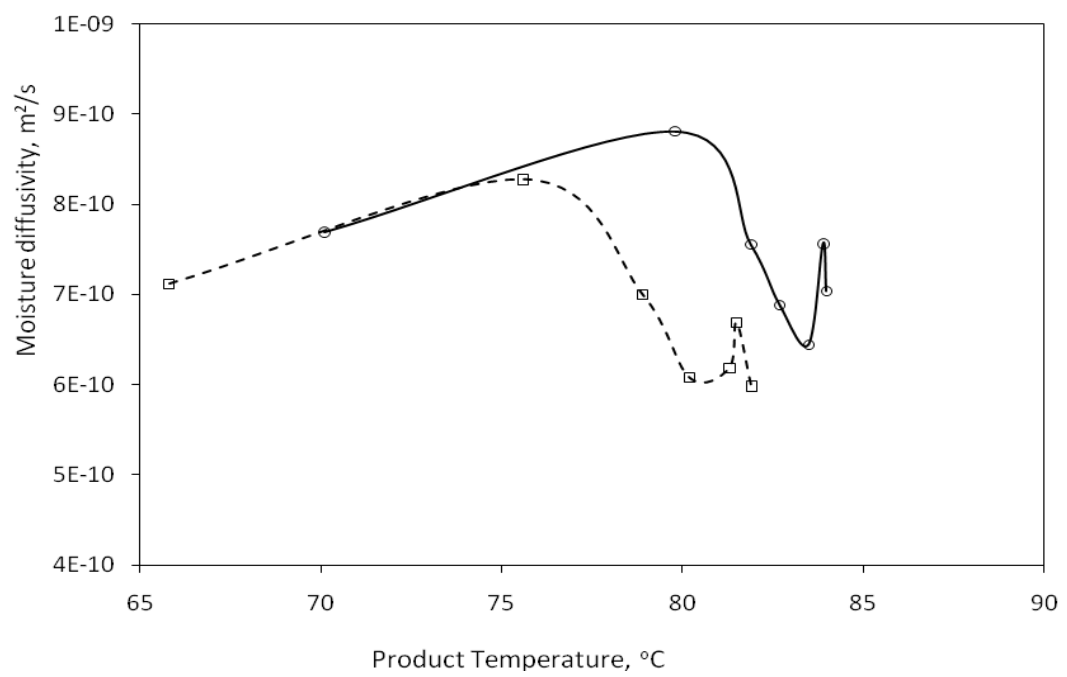

Fig. 4 - Moisture diffusivity versus mango puree temperature during $R W$ drying at two conveyor speeds $\left[0.0065 \mathrm{~m} \mathrm{~s}^{-1}(o)\right.$ and $\left.0.0078 \mathrm{~m} \mathrm{~s}^{-1}(\square)\right]$. 
There is a difference between the values of $D_{\text {eff }}$ obtained for mango puree based on the new model for RW drying and the Fick's second law of diffusion. This difference is possibly because Fick's second law of diffusion is for long drying times, but the Refractance Window drying happens in a short time, ranging from 4 to 6 minutes. Therefore, it could consider the new model to determine $D_{\text {eff }}$ for RW dying is more accurate from Fick's second law of diffusion.

By using Fick's law (equation (4)), but with simplified equation (5) for different portions of the plastic conveyor within the heating zone, it was possible to develop the relationship between moisture diffusivity for mango puree (thickness $\mathrm{L}=0.0003 \mathrm{~m}$ and assuming no shrinkage) versus drying time when the conveyor speed was $0.0065 \mathrm{~m} / \mathrm{s}$ and $0.0078 \mathrm{~m} / \mathrm{s}$.

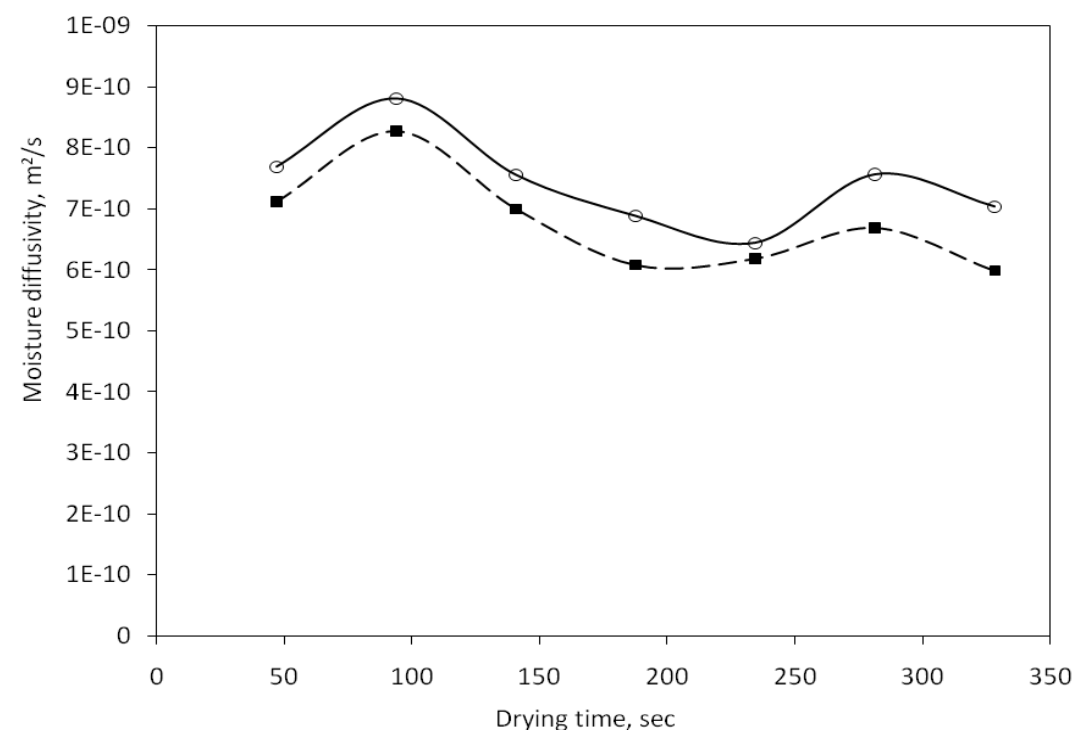

Fig. 5 - Moisture diffusivity versus drying time for mango puree using two conveyor speeds $\left[0.0065 \mathrm{~m} \mathrm{~s}^{-1}(\bullet)\right.$ and $\left.0.0078 \mathrm{~m} \mathrm{~s}^{-1}(\square)\right]$

Figure 5 shows that product temperature had a pronounced influence on the drying rate for the two selected conveyor speeds. This is because the product temperature at conveyor speed of $0.0065 \mathrm{~m} \mathrm{~s}^{-1}$ was more than at $0.0078 \mathrm{~m} \mathrm{~s}^{-1}$. For both conveyor speeds, rapid rise of product temperature soon after it is applied on the belt at the first section of dryer was evident 
in the corresponding increase in the magnitude of moisture diffusivity, $D_{\text {eff. }}$ The $D_{\text {eff }}$ value reached a maximum then decreased fast till the near of the end of drying. The increase of product temperature during the RW drying process at conveyor speeds $0.0065 \mathrm{~m} \mathrm{~s}^{-1}$ and $0.0078 \mathrm{~m} \mathrm{~s}^{-1}$ greatly affected the values of $D_{\text {eff }}$, with values ranging from $6.4-8.8 \times 10^{-10}$ and $5.85-8.49 \times 10^{-10} \mathrm{~m}^{2} \mathrm{~s}^{-1}$, respectively. These values were within the general range $10^{-6}-10^{-13} \mathrm{~m}^{2} / \mathrm{s}$ for drying of several of food materials while the majority (92\%) falls within $10^{-12}$ and $10^{-8} \mathrm{~m}^{2} \mathrm{~s}^{-1}$, (Zogzas et al. 1996). The values of $D_{\text {eff }}$ for strawberry leather ranged from $2.40 \times 10^{-9}$ to $12.10 \times 10^{-9} \mathrm{~m}^{2} \mathrm{~s}^{-1}$ depending on drying conditions (Lee and Hsieh, 2008). The diffusion coefficient at $60^{\circ} \mathrm{C}$ for apple pectin gels was $18.04 \times 10^{-10}$ $\mathrm{m}^{2} \mathrm{~s}^{-1}$ in the high-moisture region, and $1.692 \times 10^{-10} \mathrm{~m}^{2} \mathrm{~s}^{-1}$ in the lowmoisture zone (Diaz et al. 2009). Rajkumar et al. (2005) found the values of $D_{\text {eff }}$ for fresh mango pulp $0.09-0.55 \mathrm{~mm}^{2} \mathrm{~min}^{-1}$ equals $1.5-$ $9.16 \times 10^{-9}$ and for foamed mango pulp $0.17-0.97 \mathrm{~mm}^{2} \mathrm{~min}^{-1}$ equals $2.83 \times 10^{-9}-1.62 \times 10^{-8} \mathrm{~m}^{2} \mathrm{~s}^{-1}$, respectively.

\section{B. Modeling drying process and selection of best fitting model}

The coefficients of the selected 12 drying models for the two conveyor speeds $\left(0.0065\right.$ and $\left.0.0078 \mathrm{~m} \mathrm{~s}^{-1}\right)$ used in the pilot RW drying system are presented in Tables 2 and 3, respectively. The results show that the Logarithmic model had the highest values of $R^{2}$ and the lowest values of $\chi^{2}, \mathrm{RMSE}$ and EF.

Table 2 and 3 showed that generally $R^{2}$ varied between 0.9989 and $0.9995, \chi^{2}$ varied between $2.6 \times 10^{-4}$ and $7.39 \times 10^{-5}$, RMSE varied between 0.00608 and 0.01245 , and EF values varied between 0.9995 and 0.9998 , respectively. The highest $R^{2}$ and $\mathrm{EF}$ values were obtained by using the two term model, the approximation of the diffusion model and the Verma et al. model. Those three models may be selected to represent the thin layer drying behavior of mango puree. However, the results have shown that the $\chi^{2}$ and RMSE values of the two term model was slightly lower than the values obtained by approximation of the diffusion model and the Verma et al. model. Therefore, the two term model was selected to represent the thin layer drying behavior of mango puree according to the 
highest values of $R^{2}(0.9997)$ and EF (0.9998), and lowest values of $\chi^{2}$ $\left(7.39 \times 10^{-5}\right)$ and RMSE (0.00608), respectively. This result was agreed with the result for foamed mango pulp (Lee \& Hsieh, 2008). The two term model (Eq. (13)) is the appropriate model to describe thin layer drying curves of mango puree.

$$
M R=a \exp \left(-k_{1} t\right)+b \exp \left(-k_{2} t\right)
$$

Table 2 - Statistical analysis for the models for RW conveyor speed $0.0065 \mathrm{~m} \mathrm{~s}^{-1}$

\begin{tabular}{|c|c|c|c|c|c|}
\hline Mode name & Model constants & $\mathbf{R}^{2}$ & $\chi^{2}$ & RMSE & $\mathbf{E F}$ \\
\hline Newton & $\mathrm{k}=0.028$ & 0.9994 & $9.51 \mathrm{E}-05$ & 0.00912 & 0.99958 \\
\hline Henderson & $\mathrm{a}=0.999, \mathrm{k}=0.028$ & 0.9994 & $1.11 \mathrm{E}-04$ & 0.00912 & 0.99958 \\
\hline Page & $\mathrm{k}=0.042, \mathrm{n}=0.902$ & 0.9995 & 8.99E-05 & 0.00821 & 0.99967 \\
\hline $\begin{array}{l}\text { Modified } \\
\text { Page }\end{array}$ & $\mathrm{k}=0.030, \mathrm{n}=0.902$ & 0.9995 & 8.99E-05 & 0.00821 & 0.99967 \\
\hline Logarithmic & $\begin{array}{l}\mathrm{a}=0.983, \mathrm{k}=0.029 \\
\mathrm{c}=0.017\end{array}$ & 0.9997 & $7.45 \mathrm{E}-05$ & 0.00683 & 0.99978 \\
\hline *Two-term & $\begin{array}{l}\mathrm{a}=0.941, \mathrm{k}_{1}=0.032, \\
\mathrm{~b}=0.059, \mathrm{k}_{2}=0.008\end{array}$ & 0.9997 & 7.39E-05 & 0.00608 & 0.99982 \\
\hline $\begin{array}{l}\text { Two-term } \\
\text { exponential }\end{array}$ & $\mathrm{a}=0.519, \mathrm{k}=0.040$ & 0.9996 & 7.56E-05 & 0.00753 & 0.99972 \\
\hline Midilli et al. & $\begin{array}{l}\mathrm{a}=1, \mathrm{~b}=0.00004 \\
\mathrm{n}=0.947, \mathrm{k}=0.036\end{array}$ & 0.9996 & $1.09 \mathrm{E}-04$ & 0.00739 & 0.99973 \\
\hline $\begin{array}{l}\text { Diffusion } \\
\text { approximation }\end{array}$ & $\begin{array}{l}\mathrm{a}=0.941, \mathrm{~b}= \\
0.242, \mathrm{k}=0.031\end{array}$ & 0.9997 & 7.48E-05 & 0.00684 & 0.99978 \\
\hline Verma et al. & $\begin{array}{l}\mathrm{a}=0.941, \mathrm{k}= \\
0.031, \mathrm{~g}=0.008\end{array}$ & 0.9997 & $7.48 \mathrm{E}-05$ & 0.00684 & 0.99978 \\
\hline $\begin{array}{l}\text { Simplified } \\
\text { Fick's }\end{array}$ & $\mathrm{a}=0.999, \mathrm{k}=0.003$ & 0.9994 & $1.11 \mathrm{E}-04$ & 0.00912 & 0.99958 \\
\hline $\begin{array}{l}\text { Modified } \\
\text { Page II } \\
\end{array}$ & $\mathrm{n}=0.902, \mathrm{k}=0.005$ & 0.9995 & $8.99 \mathrm{E}-05$ & 0.00821 & 0.99967 \\
\hline
\end{tabular}

* This model gives the closest result to the experimental results 
PROCESS ENGINEERING

Table 3 - Statistical analysis for the models for RW conveyor speed $0.0078 \mathrm{~m} \mathrm{~s}^{-1}$

\begin{tabular}{|c|c|c|c|c|c|}
\hline Mode name & Model constants & $\mathbf{R}^{2}$ & $\chi^{2}$ & RMSE & $\mathbf{E F}$ \\
\hline Newton & $\mathrm{k}=0.028$ & 0.9989 & $1.77 \mathrm{E}-04$ & 0.01245 & 0.99927 \\
\hline Henderson & $\mathrm{a}=0.999, \mathrm{k}=0.028$ & 0.9989 & $2.06 \mathrm{E}-04$ & 0.01244 & 0.99927 \\
\hline Page & $\mathrm{k}=0.042, \mathrm{n}=0.902$ & 0.9992 & $1.56 \mathrm{E}-04$ & 0.01081 & 0.99947 \\
\hline $\begin{array}{l}\text { Modified } \\
\text { Page }\end{array}$ & $\mathrm{k}=0.030, \mathrm{n}=0.902$ & 0.9992 & $1.56 \mathrm{E}-04$ & 0.01081 & 0.99947 \\
\hline Logarithmic & $\begin{array}{l}\mathrm{a}=0.983, \mathrm{k}=0.029, \\
\mathrm{c}=0.017\end{array}$ & 0.9991 & 2.01E-04 & 0.01120 & 0.99948 \\
\hline *Two-term & $\begin{array}{l}\mathrm{a}=0.941, \mathrm{k}_{1}=0.032 \\
\mathrm{~b}=0.059, \mathrm{k}_{2}=0.008\end{array}$ & 0.9995 & $1.29 \mathrm{E}-04$ & 0.00803 & 0.99972 \\
\hline $\begin{array}{l}\text { Two-term } \\
\text { exponential }\end{array}$ & $\mathrm{a}=0.519, \mathrm{k}=0.040$ & 0.9993 & $1.33 \mathrm{E}-04$ & 0.01000 & 0.99954 \\
\hline Midilli et al. & $\begin{array}{l}\mathrm{a}=1, \mathrm{~b}=0.00004 \\
\mathrm{n}=0.947, \mathrm{k}=0.036\end{array}$ & 0.9993 & $1.89 \mathrm{E}-04$ & 0.00972 & 0.99958 \\
\hline $\begin{array}{l}\text { Diffusion } \\
\text { approximation }\end{array}$ & $\begin{array}{l}a=0.941, b=0.242, \\
k=0.031\end{array}$ & 0.9995 & $1.03 \mathrm{E}-04$ & 0.00803 & 0.99972 \\
\hline Verma et al. & $\begin{array}{l}\mathrm{a}=0.941, \mathrm{k}=0.031, \\
\mathrm{~g}=0.008\end{array}$ & 0.9995 & $1.03 \mathrm{E}-04$ & 0.00803 & 0.99972 \\
\hline $\begin{array}{l}\text { Simplified } \\
\text { Fick's }\end{array}$ & $\mathrm{a}=0.999, \mathrm{k}=0.003$ & 0.9989 & $2.06 \mathrm{E}-04$ & 0.01244 & 0.99927 \\
\hline $\begin{array}{l}\text { Modified } \\
\text { Page II }\end{array}$ & $\mathrm{n}=0.902, \mathrm{k}=0.005$ & 0.9992 & $1.56 \mathrm{E}-04$ & 0.01081 & 0.99947 \\
\hline
\end{tabular}

* This model gives the closest result to the experimental results

The performance of the two-term model at two different conveyor speeds $\left(0.0065\right.$ and $\left.0.0078 \mathrm{~m} \mathrm{~s}^{-1}\right)$ for the RW pilot dryer are illustrated in Fig. 6 and Fig. 7. The predicted data generally banded around the straight line which showed the suitability of two-term model for describing drying behavior of mango puree. 


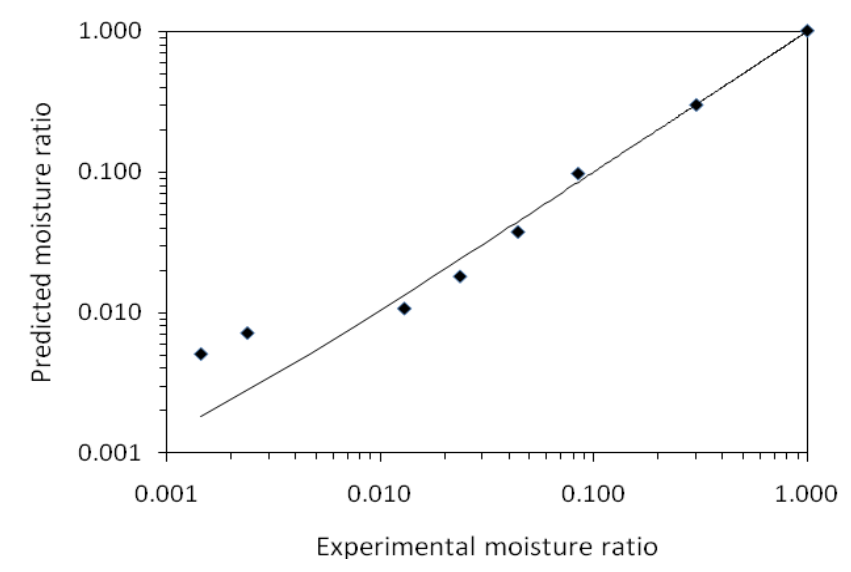

Fig. 6 - Experimental moisture ratio versus predicted moisture ratio by two term model for conveyor speed $0.0065 \mathrm{~m} \mathrm{~s}^{-1}$.

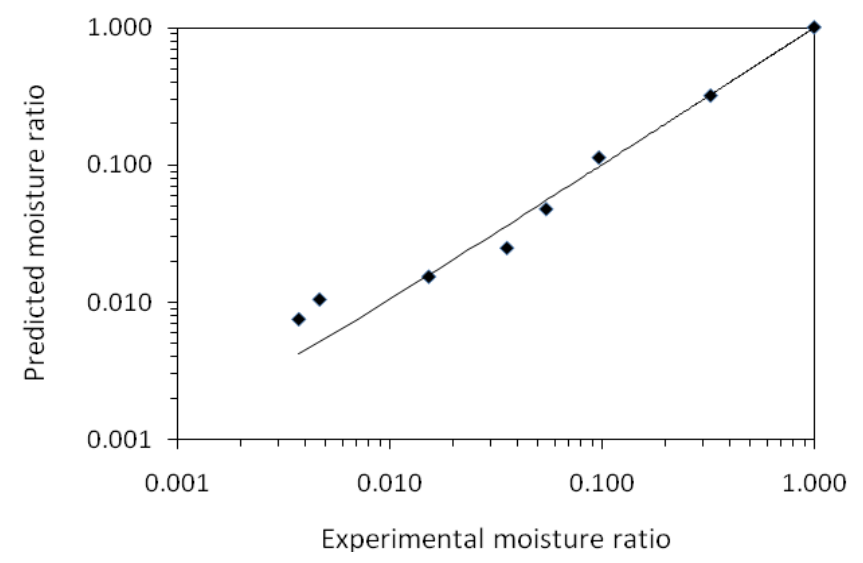

Fig. 7 - Experimental moisture ratio versus predicted moisture ratio by two term model for conveyor speed $0.0078 \mathrm{~m} \mathrm{~s}^{-1}$

Residual plots of different models for thin layer drying of mango puree are shown in Figures 8 and 9.

For the Two-term model, the residual plots indicated a scattered pattern and the residuals are very close to $\mathrm{X}$-axis leads to the interference that this model is suitable for predicting thin layer drying of mango puree.

For other models, the residual plots indicated a systematic pattern and the residuals are not close to $\mathrm{X}$-axis, which means that these models are not well fitted to experimental data. 


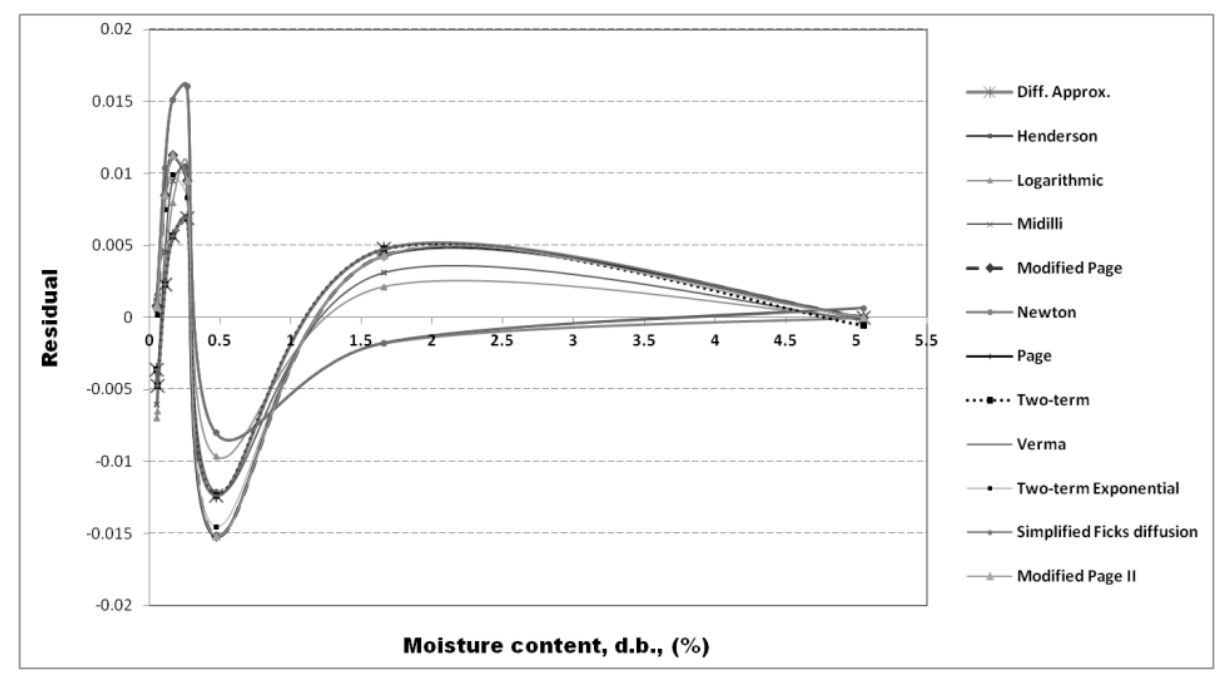

Figure 8: Residual plots of different models for thin layer drying of mango puree at conveyor speed $0.0065 \mathrm{~m} / \mathrm{s}$

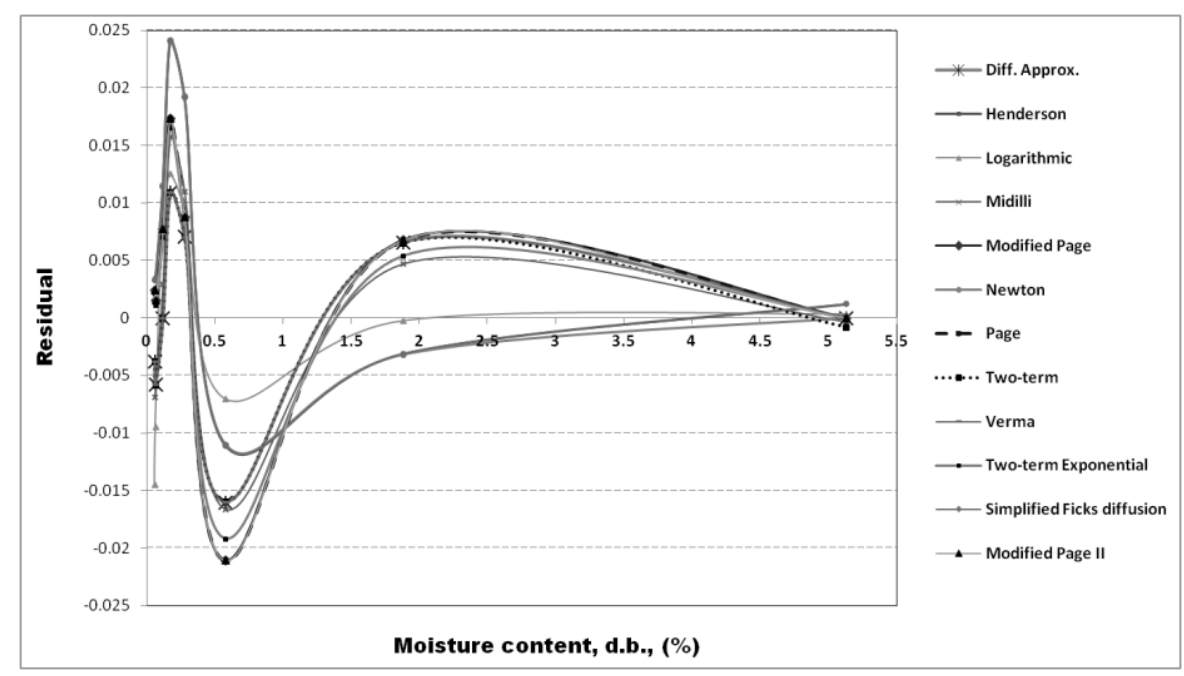

Figure 9: Residual plots of different models for thin layer drying of mango puree at conveyor speed $0.0078 \mathrm{~m} / \mathrm{s}$

\section{CONCLUSION}

The drying of mango puree in a pilot Refractance Window dryer was investigated and the experimental data modeled by fitting twelve thin layer equations by direct least squares procedure. Moisture diffusivity and change in moisture ratio were used to characterize the drying behavior at 
two selected conveyor belt speeds. The drying characteristics of mango puree at different drying conditions were studied and model parameters, namely, coefficient of determination $\left(\mathrm{R}^{2}\right)$, reduced mean square of the deviation $\left(\chi^{2}\right)$, root mean square error (RMSE) and modeling efficiency (EF) used to rank the thin layer drying models. A two-term model was found to be the best model for describing the drying kinetics of the mango puree in a RW drying system. This result was agreed with the result for foamed mango pulp (Lee and Hsieh, 2008). The drying rate was affected by the product temperature and the conveyor speed. The moisture diffusivity was $6.07 \times 10^{-10}$ and $8.74 \times 10^{-10} \mathrm{~m}^{2} / \mathrm{s}$ at conveyor speeds of $0.0065 \mathrm{~m} \mathrm{~s}^{-1}$ and $0.0078 \mathrm{~m} \mathrm{~s}^{-1}$, respectively.

\section{RECOMMANDITIONS}

1. Reducing the drying time of juices and purees could be obtained by Refractance Window drying system compared to other methods.

2. This Pilot unit of RW drying system can be used to determine the moisture diffusivity of other juices and purees.

\section{REFERENCES}

Afzal, T. M. and Abe, T. (2000). Simulation of moisture changes in barley during far-infrared radiation drying. Comput. Electron. Agric., 26(2): 137-145.

Akpinar, E., Midilli, A. and Bicer, Y. (2003). Single layer drying behavior of potato slices in a convective cyclone and mathematical modeling. Energy Conversion Management, 44, 1689-1705.

Cengel, Y. A. (2003). Heat Transfer: A Practical Approach, $2^{\text {nd }}$ ed., McGraw-Hill.

Chakraverty, A. and Singh, R. P. (1988). Post Harvest Technology of Cereals, Pulses and Oilseeds, Oxford and IBH Publishing Co. Pvt. Ltd, New Delhi, India.

Chhinnan, M. S. (1984). Evaluation of selected mathematical models for describing thin-layer drying of in-shell pecans. Transactions of the ASAE, 27, 610-615.

Crank, J. (1975). The Mathematics of Diffusion; Oxford University Press: Oxford. 
Diamante, L. M. and Munro, P. A. (1991). Mathematical modeling of hot air drying of sweet potato slices. International Journal of Food Science and Technology, 26, 99-109.

Díaz, E. L., Giannuzzi, L. and Giner, S. A. (2009). Apple Pectic Gel Produced by Dehydration. Food Bioprocess Technology, 2:194207.

Goyal, R. K., Kingsly, A. R. P., Manikantanl, M. R. and Ilyas, S. M. (2006). Thin-layer drying kinetics of raw mango slices. Biosystems Engineering, 95(1), 43-49.

Henderson, S. M. (1974). Progress in developing the thin layer drying equation. Transactions of the ASAE, 17, 1167-1172.

Karathanos, V. J. and Belessiotis, V. G. (1999). Application of a thinlayer equation to drying data of fresh and semi-dried fruits. Journal of Agricultural Engineering Research, 74, 355-361.

Kassem, A. S. (1998). Comparative studies on thin layer drying models for wheat. In Proceedings of the 13th international congress on agricultural engineering, Morocco.

Lee, G. and Hsieh, F. (2008). Thin-layer drying kinetics of strawberry fruit leather. Transactions of the ASABE, 51(5): 1699-1705

Madamba, P. S. (2003). Thin layer drying models for osmotically predried young coconut. Drying Technology, 21, 1759-1780.

Maskan, A., Kaya S. and Maskan, M. (2002). Hot air and sun drying of grape leather (pestil). Journal of Food Engineering, 54(1): 81-88.

Midilli A., Kucuk H. and Yapar Z. (2002). A new model for single layer drying. Drying Technology, 20: 1503-1513.

Nindo, C. I., Wang, S. W., Tang, J. and Powers, J. R. (2003). Evaluation of drying technologies for retention of physical and chemical quality of green asparagus (Asparagus officinalis L.). Journal of Food Science and Technology (LWT), 36, 507-516.

Nindo, C.I., Tang, J., Powers, J. R. and Bolland, K. (2004). Energy consumption during Refractance Window evaporation of selected berry juices. International Journal of Energy Research, 28, 10891100 . 
Nindo, C. I. and Tang, J. (2007). Refractance Window Dehydration Technology: A Novel Contact Drying Method. Drying Technology, 25: $37-48$.

Nindo, C. I., Powers, J. R. and Tang, J. (2007). Influence of Refractance Window evaporation on quality of juices from small fruits. $L W T, 40,1000-1007$.

Rahman, M. S. and Lamb, J. (1991). Air drying behavior of fresh and osmotically dehydrated pineapple. Journal of Food Process Engineering, 14 (3), 163-171.

Rahman, M. S., Perera, C. O. and Thebaud, C. (1998). Desorption isotherm and heat pump drying kinetics of peas. Food Research International, 30 (7), 485-491.

Rajkumar, P., Kailappan, R., Viswanathan, R., Raghavan, G. S. V. and Ratti, C. (2005). Studies on foam mat drying on alphonso mango Pulp. Inter American Drying Conference (IADC), McGill University, Montreal, Canada.

Ratti, C. and Kudra, T. (2006). Drying of Foamed Biological Materials: Opportunities and Challenges. Drying Technology, 24: 9, 1101 1108.

Sarsavadia, P. N., Sawhney, R. L., Pangavhane, D. R. and Singh, S. P. (1999). Drying behavior of brined onion slices. Journal of Food Engineering, 40, 219-226.

Sharaf-Eldeen, Y. I., Blaisdell, J. L. and Hamdy, M. Y. (1980). A model for ear corn drying. Transaction of the ASAE, 23, 12611271.

Togrul, I. T. and Pehlivan, D. (2003). Modelling of drying kinetics of single apricot. Journal of Food Engineering, 58: 23-32.

Vengaiah, P. C. and Pandey, J. P. (2007). Dehydration kinetics of sweetpepper (Capsicum anuum L.). Journal of Food Engineering, 81: 282-286.

Verma, L. R., Bucklin, R. A., Endan, J. B. and Wratten, F. T. (1985). Effects of drying air parameters on rice drying models. Transaction of the ASAE, 28, 296-301. 
White, G. M., Ross, I. J. and Ponelert, R. (1981). Fully exposed drying of popcorn. Transactions of the ASAE, 24, 466-468.

Zogzas, N. P., Maroulis, Z. B. and Marinos-Kouris, D. (1996). Moisture Diffusivity Data Compilation in Foodstuffs. Drying Technology, 14: (10), 2225 - 2253.

\section{الملخص العربيى}

خصائص الطبقة الرقيقة لمهروس (عصير) المانجو فى نظام التجفيف بالناقذة المنعكسة (عصيزة د. باهر محمود أحمد عامر

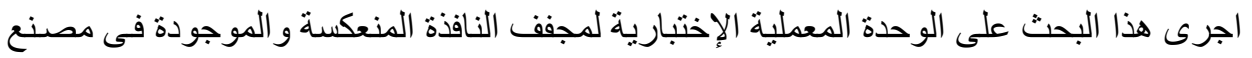

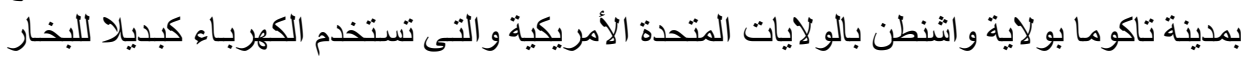

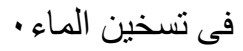

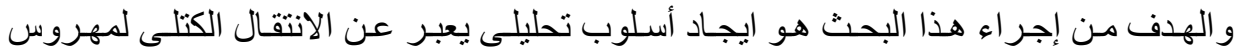

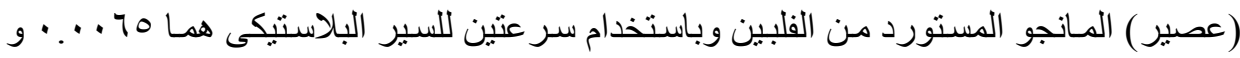

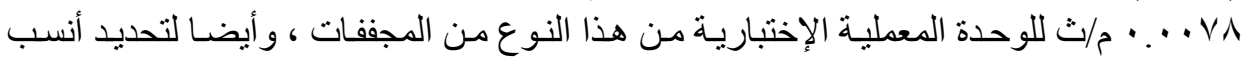

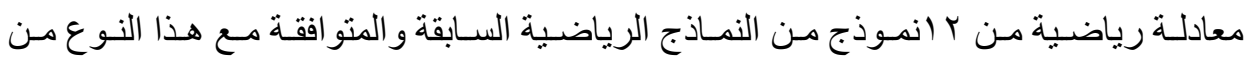

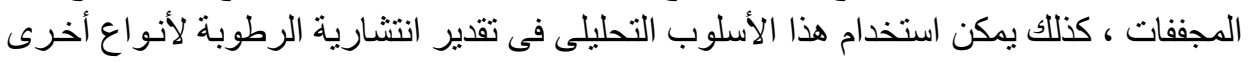

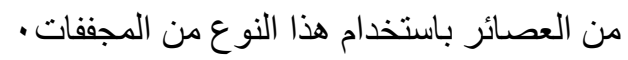

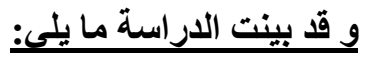

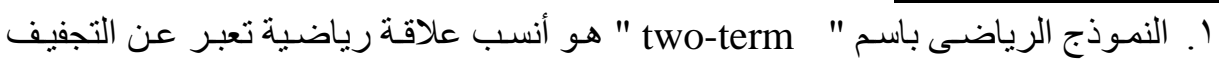
للطبقة الرقيقة من عصير المانجو باستخدام المجفف ذو النافذة المنعكسة.

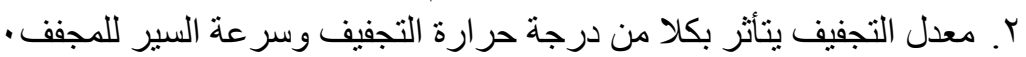

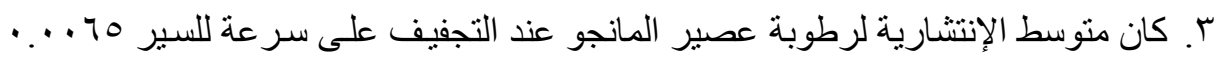

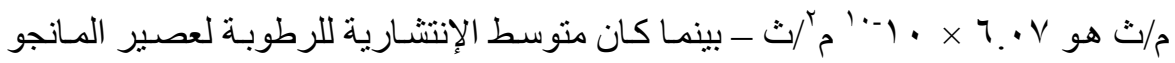

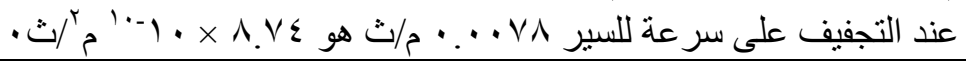

\section{التوصيات}

ا ـ يمكن تقليل زمن تجفيف العصائر و المهروسات باستخدام مجفف ذو النافذة المنعكسة مقارنة بالطرق الأخرى لتجفيف نفس المنتجات.

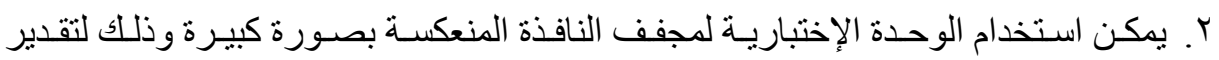

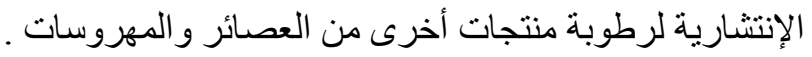

*مدرس الهندسة الزراعية ـ كلية الزراعة ـ جامعة القاهرة 